\title{
In Science Communication, why does the Idea of a Public Deficit Always Return?
}

\author{
Meyer, Gitte
}

Document Version

Accepted author manuscript

Published in:

Public Understanding of Science

DOI:

$10.1177 / 0963662516629747$

Publication date:

2016

License

Unspecified

Citation for published version (APA):

Meyer, G. (2016). In Science Communication, why does the Idea of a Public Deficit Always Return? Public Understanding of Science, 25(4), 433-446. https://doi.org/10.1177/0963662516629747

Link to publication in CBS Research Portal

\section{General rights}

Copyright and moral rights for the publications made accessible in the public portal are retained by the authors and/or other copyright owners and it is a condition of accessing publications that users recognise and abide by the legal requirements associated with these rights.

\section{Take down policy}

If you believe that this document breaches copyright please contact us (research.lib@cbs.dk) providing details, and we will remove access to the work immediately and investigate your claim.

Download date: 26. Apr. 2023 


\section{In Science Communication, why does the Idea of a Public Deficit Always Return? \\ Gitte Meyer}

Journal article (Accepted version)

CITE: In Science Communication, why does the Idea of a Public Deficit Always Return? / Meyer,

Gitte. In: Public Understanding of Science, Vol. 25, №. 4, 2016, p. 433-446.

Copyright (C) The Author(s) २०16. Reprinted by permission of SAGE Publications.

DOI: $\underline{10.1177 / 0963662516629747}$

Uploaded to Research@CBS: December 2017 
This document contains the text that was accepted for publikation as:

Meyer, Gitte: (2016): In science communication, why does the idea of a public deficit always return? Public Understanding of Science 25 (4): 433-446. DOI: 10.1177/0963662516629747 Please use the published version if you wish to quote the article.

\title{
Essay: \\ In Science Communication, why does the idea of a public deficit always return?
}

\begin{abstract}
For centuries, science communication has been widely perceived, irrespective of context, as a didactic enterprise. That understanding does not accommodate a political category of science communication, featuring citizens on an equal footing - some of them scientists - who share responsibility for public affairs and represent different points of view and ways of reasoning. That may harm, at the same time and for the same reasons, democratic knowledge societies as political entities and science as a body of knowledge and rational methodology. Scientists are discursively excluded from the public. The public is perceived in terms of knowledge deficiency.

The latter perception has survived decades of critique, accompanied by attempts, along an everyman-asscientist logic, to include all citizens in the scientific endeavour. But why should all be scientists? With respect to practical-political issues - as distinct from technical-scientific ones - the acknowledgement of the citizenship of scientists seems more relevant. Only, this would challenge the widespread understanding of science as an all-purpose problem-solver, and the consequent ideas of politics.
\end{abstract}

Keywords: deficit model; science didactics; popularisation; knowledge societies; science in society; practical reason.

For centuries, science communication has been widely perceived, irrespective of context, as a didactic enterprise. Didactics makes sense only on the assumption of a knowledge deficit in students or pupils. In science teaching that assumption is uncontroversial. From a democratic point of view, however, grave problems arise when public exchanges regarding the steadily increasing number of science-related public affairs are seen as instances of an overall didactic enterprise aimed at a knowledge deficient general public. The roles of (mature) citizen and (immature) pupil are confused. Political disagreement easily comes to be seen as the expression of inadequate knowledge. Discursively excluded from the general public scientists appear as non-citizens. It seems urgent - to science and the societies it forms part of - to understand how the general didactic understanding of science communication and the idea of a public deficit may have come about, and to ponder whether it might be possible to use different approaches, depending on the context.

It would seem reasonable to operate with substantially different categories of science communication, such as a didactic category of science teaching and a political category of public discussion of science-related public affairs. Here, the latter category will be in focus, recognising that the boundaries among such categories would never be beyond dispute and that in practice they might frequently overlap. I will make the case, that science communication discourses have been marked continuously by a conspicuous absence of substantial ideas of politics. At a basic level, the ancient idea of science as 'Universal Light' (Sprat, 1966/1667: 81), with the potential to answer all kinds of worldly questions, appears to have survived centuries of science discussions - and with it, in particular, the attendant negation of politics as anything other than either the irrational opposite or the rational application of science. As a consequence, there is no place for a category of science communication as a variety of what has been characterised as the political core activity (Crick, 2005/1962): exchange between different points of view among citizens who share a capacity for reason. That, in turn, at the same time and for the same reasons, may harm democratic knowledge societies as political entities and science as a body of knowledge and rational methodology.

Inserting science communication into a framework of classical political thought the concluding section illustrates that science communication and assumptions of a deficient public are not logically inseparable. Based, firstly, on a distinction between technical-scientific and practical- 
political issues and, secondly, on the acknowledgement of scientists as citizens, a political category of science communication is sketched out and linked specifically to science-related practicalpolitical issues. In conclusion, tension is noted between the proposed category and the idea of science as universal light.

\section{A DIDACTIC ENTERPRISE}

For several inter-connected reasons the following discussion will focus on English-spoken, and in particular British approaches to science communication. Firstly, the idea of science communication as a didactic enterprise relates to the English language concept of science - including the natural and social sciences - as distinct, for instance, from the German and Scandinavian concepts of Wissenschaft, videnskab (Danish), vitenskap (Norwegian) or vetenskap (Swedish), all of which include the humanities. Secondly, during the most recent half-century international exchanges on science communication have been increasingly English-spoken and, thus, have been drawing on English-spoken concepts and notions. Thirdly, discussions and developments within the EU seem to have been highly influenced by discussions and developments in the UK. Influences from the USA have, no doubt, been significant (see for instance Royal Society, 1985), but in order not to bite off more cultural differences than any single essay could possibly chew, the emphasis here will be on Europe.

Roughly since the 1980s, science communication has evolved into a professional activity and an academic topic in its own right and has been spoken about as a technical dissemination task, using producer-consumer terms (Friedman et al., 1986). Current European exchanges on science communication are informed by metaphors from the sphere of production. Construction, consumption, toolboxes and effective communication are examples. Science communication appears as the final unit in a chain of production. Scientific knowledge is seen as a product and a good for possession, distribution and consumption. "Upstream", scientists produce knowledge to be packaged and transported "downstream" to non-scientists as potential consumers.

The overall production and diffusion simile is applied to different, and even to some extent conflicting, purposes such as marketing (selling particular scientific outcomes or branding institutions), missionary activities (spreading belief in science) or democratisation (seeing scientific knowledge as a good that ought to be equally shared by all). All these activities are seen as instances of the transfer of knowledge from knowers to non-knowers: this is a didactic understanding of science communication. That understanding, in turn, clearly continues much older efforts - as old as modern science itself - to spread knowledge of (natural) science and, in the process, to convince non-scientists of the value of science and, even, to further science-based opinion formation.

The purpose of dissemination presupposes a deficit at the receiving end. It works on a deficit model of target groups, including the general public. Thus, rather than constituting two separate models - a dissemination and a deficit model, respectively (McNeil, 2013) - both the purpose of dissemination and the assumption of a deficit in the target groups seem to form part of a didactic framework. During the most recent decades, socio-technical approaches have been added. Connected to general trends in didactics and innovation research, attempts are made to include nonscientific consumers of scientific knowledge as co-producers of such knowledge, viewing the chain of production as a production loop. Dialogue has come to be seen as the proper and most effective didactic tool. There has been a general change of didactic means; and there has been critique of the idea of a public deficit and debate about the persistence of that very idea.

As a term, "the deficit model" was introduced by its critics. The assumption of a public deficit vis-à-vis science is, however, much older than the present terminology. It is already present 
in the term of the laity, signifying a group of people in lack of knowledge. The term was inherited from the medieval church and is still widely used.

In its most basic form, the deficit model simply signifies the assumption that there is inadequate knowledge of science in the general public. In a further step, such knowledge inadequacy may be linked, as a cause-effect connection, to attitudes towards science - 'the role of scientific knowledge in explaining people's attitudes towards science' (Sturgis and Allum, 2004) assuming inadequate knowledge of science to result in lack of appreciation of science. Critics have called this 'the knowledge-attitudes model of the Royal Society: the more you know, the more you love it' (Bauer, 2009). Yet other critics have been particularly keen to expose 'the deficit model (mis)understanding of public dissent' (Welsh and Wynne, 2013); that is, attempts to explain opposition to specific technological endeavours as the outcome of inadequate knowledge.

The two latter varieties both make leaps from knowledge to attitudes or, if you like, from description to normativity. This has been criticised (Bauer et al., 2007) and the leaps do indeed appear odd, considering that one of the founding features of modern science is a commitment to pure description as opposed to normativity. In science, the naturalistic fallacy of concluding from "is" to "ought" is widely condemned. In science dissemination efforts, however, a teachingpreaching ambiguity has, for centuries, been a staple. Is that ambiguity somehow related to the understanding of science communication as nothing but a didactic enterprise?

\section{SCIENCE ENTHUSIASM}

Acknowledging the movement aspect of modern science may take us some way towards understanding the persistent dominance of the didactic frame. Modern science is, of course, much more than a movement. First and foremost, it is a body of knowledge and rational methodology, maintained globally by millions of scientists, aiming to come up with true, universally correct explanations of and solutions to technical questions and problems. Nevertheless, modern science came into being as a movement, dedicated to faith in science as a cause; and aims of conversion the wish to move others to share the cause - have been present from the 1660 s onwards. The understanding of science as a cause, the cause of universal light, forms part of the background of the assumed unity of science communication as an overall didactic enterprise.

\section{A war against 'Ignorance and False Opinions'}

When seen from within, this movement aspect of modern science is difficult, and perhaps, to some, even painful, to recognise and cope with. This is because the peculiar modern trait of antienthusiastic enthusiasm seems particularly strongly expressed in modern science. Born in the wake of the English civil wars, it became marked in a round-about way by the fear of enthusiasm (Coltman, 1962) those religious wars had brought about. In a sense, it began its life as an antimovement movement.

Writing the first history of the Royal Society, Thomas Sprat - one of the first propagandists of science as a cause - reported enthusiastically that young men were now being 'armed against all the inchantments of Enthusiasm' (Sprat, 1966/1667: 53). Dislike of politics formed part of the package. The founders of the society, Sprat went on, did not meet to discuss 'civil business, and the distresses of their Country' and did not concern themselves with 'politicks, morality and oratory' (Sprat, 1966/1667: 82). Actually, he argued 'the consideration of Men, and humane affairs may affect us with a thousand various disquiets', but the contemplation of Nature 'never separates us into mortal Factions; that gives us room to differ, without animosity; and permits us to raise contrary imaginations upon it, without any danger of a Civil War' (Sprat, 1966/1667: 55-56). 
Sprat, thus, expressed a striving: by allowing people to differ without animosity the new science should contribute to preserving the peace. The fear of enthusiasm expressed a dread of substantial disagreement. It originated in experiences with sectarian violence carried out by fanatics in the name of Truth. Sprat was equally convinced that the new science was a source of universal truth - the 'true Remedy', redeeming 'the minds of Men, from obscurity, uncertainty, and bondage' (Sprat, 1966/1667: 58). Only, the belief in scientific truth was different. Based on pure observation as opposed to enthusiastic participation by potentially fanatical individuals and groups, scientific truth qualified as a representative of light as opposed to darkness and of consensus and unity as opposed to conflict and division. All civil nations should, Sprat argued, join the armies in this 'philosophical war' against the 'powerful and barbarous Foes' of 'Ignorance, and False Opinions' (Sprat, 1966/1667: 57). Although wishing to preserve peace, Sprat could not help it: he was at war. His aims did not include exchange and reciprocity with other groups in society. Conversion was the overall aim. To that purpose, teaching and preaching, or education and persuasion, were one.

Viewing the history of modern science from a much greater distance of time and stance, historian Herbert Butterfield has noted that the scientific movement as a new factor in the seventeenth century 'immediately began to elbow the other ones away, pushing them from their central position. Indeed, it began immediately to seek control of the rest, as the apostles of the new movement had declared their intention of doing from the very start' (Butterfield, 1957/1949: 206). The movement, Butterfield found, was marked by a 'passion to extend the scientific method to every branch of thought', accompanied by 'a sort of technological fervour' (Butterfield, 1957/1949: 185).

In the early eighteenth century, according to a relatively recent history of the British enlightenment, science was 'energetically promoted amongst the public. Initially in London's coffee houses, lecturers began to offer demonstrations with globes, orreries and other instruments displaying the marvels of the clockwork universe, while performing chemical, magnetic, electrical and airpump experiments besides' (Porter, 2001: 142). The Spectator of 1711 looked forward to the time " "when Knowledge, instead of being bound up in Books, and kept in Libraries and retirement, is thus obtruded upon the Publick; when it is canvassed in every Assembly, and exposed upon every Table"" (Porter, 2001: 194).

Writing in the 1930s, but hardly a less enthusiastic representative of the scientific movement than Sprat, historian John B. Bury described the second half of the nineteenth century as being marked by 'rapidly growing demand (especially in England) for books and lectures, making the results of science accessible and interesting to the lay public'. This 'popular literature', Bury found, was 'subtly flushing the imaginations of men with the consciousness that they were living in an era which, in itself vastly superior to any age of the past, need be burdened by no fear of decline or catastrophe, but trusting in the boundless resources of science might securely defy fate' (Bury, 1955/1932: 345-346).

The commitment to science as a cause has shown itself in radically utopian fantasies, characterised by undisguised run-away enthusiasm (see for instance Midgley, 1992). At the same time, the idea of science as universal light also gradually became naturalised - in particular, probably, in Britain - as a quiet and seemingly pragmatic, secular, even profane, everyday understanding of science as an all-purpose problem-solver. The argument that decisions should be 'made in the light of an adequate understanding of the issues' (Bodmer, 2010) appears to be no more than common sense but may, nevertheless, be based on a deeply rooted belief that science, epitomising reason and realism, is capable of providing all necessary understanding, has no limits and is somehow beyond beliefs and personal judgements.

Public representations of science has been a feature of public life in Europe for centuries. Now and again, these representations have been highly passionate. Until relatively recently, 
however, all such representations had to take place within a non-scientific, societal space. The diffusion of scientific approaches to most activities and professions was a thing of the future. Moreover, until the early twentieth century, scientific specialisation was still sufficiently limited for Ernest Rutherford (1871-1939) to remark that 'no physics could be good, unless it could be explained to a barmaid' (Hobsbawm, 1995: 538). In practice, scientists formed part of wider society; science was practised, taught and preached in a wider, non-scientific context and was, for good or worse, not immune from influences from society at large.

\section{Popularisation: targeting the 'unknowing multitude'}

Probably from a very early stage, the use of the concept of the laity, originally signifying a lack of (religious) knowledge, has also implied other connotations. Not least, a rich heritage of social prejudice is likely to have been informing the continuous tendency to view science communication as a social relationship between scientific elites and lay masses of so-called ordinary people or average citizens.

Such expressions as the 'meaner sort of people', 'the common and meaner sort', 'the lower orders' and 'the rabble' (Hill, 2010/1961: 67,85,207,239) obviously were staples of seventeenth century discourse. They were related to knowledge and learning in such combinations as 'th' unknowing multitude' (Hill, 2010/1961: 101) and 'the rabble that cannot read' (Morgan, 1989: 92). Gradually the openly abusive expressions were replaced by less immediately demeaning labels.

In 1929, for instance, when H.G. Wells, his son G.P. Wells and the renowned biologist Julian Huxley launched a popular science magazine, The Science of Life, they declared their publication to be targeting 'the ordinary man' (Wells et al., 1929-1930: 2). They also repeatedly emphasised their belief in the superiority of science and their contempt of "the crowd". Denouncing, for instance, '[v]ulgar fashions, false interpretations and decaying traditions' they noted: '[T]he crowd is always about us; but we forget that these things are divergent and inconsecutive and accumulate no force, while scientific work and lucid thought are persistent and cumulative' (Wells et al., 1929-1930: 973). Typical of the period, these authors were obsessed with eugenics as a way of dealing with the sad imperfections of humankind. In line with Sprat's twin aims of fighting the foes of ignorance and false opinions, the science popularisation initiative seems to have been launched to educate the general public and to further the cause of eugenics.

At that time, the notion of "science popularisation" had been in use for about a century (Chambers, 2006). Although nowadays sometimes accompanied by slight misgivings (Cooter and Pumfrey, 1994; McNeil, 2013), it is still widely used as a general science communication term and appears, at first glance, to be connected directly to the concept of the public - adult population, from populus (Chambers, 2006) - which in modern democratic societies constitutes the citizenry. Popularisation of science, however, presupposes the existence of popularising scientists who, although adult, seem not to form part of the public. Actually, the juxtaposition of scientists and the public - even of scientists and citizens - is a continuous feature of science communication discourses. It seems a reasonable interpretation that the idea of popularisation should be connected, not to the political concept of the public, but rather to the social category of commoners or plebeians, originating in a Greek term for crowd or throng (Chambers, 2006) and, thus, related to the highly ambiguous concept of the masses.

As a quantitative term the concept of the masses simply signifies the many, the majority. As a qualitative term it implies certain expectations of that majority. Those expectations, among other things, connect the masses with emotional sensibilities rather than intellectual leanings, and with concerns with the here-and-now rather than with that which is further away in either space or time (see also Arendt, 1958-1959). From an elitist point of view, such assumed features give cause for contempt. Maintaining the basic assumptions, but standing the elitist normative assessment on its 
head, we arrive at a positive understanding of the supposed masses in the shape of "the people" as a warm-hearted collective of ordinary men and women, all motivated primarily by everyday concerns, unlettered, dedicated to local and community affairs and driven by deeply rooted moral instincts. We end up with populism as inverted elitism, celebrating instead of expressing contempt of "the unknowing multitude".

Because the basic assumptions remain unchanged, populism may easily revert to elitism, and vice-versa, creating an elitism-populism axis. Nowhere along that axis are intellectual capacities ascribed to the general public. The idea of an intellectual deficit in the general public is one of its founding features. Against that background, it seems relevant to ask to what extent understandings of science communication are and have been linked to that kind of axis, deriving in a nonegalitarian context and likely to reproduce that feature over and over again.

Interestingly, both Thorstein Veblen, representing typical populist views, and José Ortega y Gasset, representing typical elitist views, connected science, as distinct from humanist scholarship, to the masses (Ortega y Gasset, 1993/1930; Veblen 1899). Also, the populist feature of antiintellectualism - another ambiguous notion - has frequently been related to science (Porter, 2001: 23; Porter, 1995: 195; Wood, 1993: 240,369). And returning to Sprat, we find that he expressed a preference for 'the language of Artizans, Countrymen and Merchants, before that, of Wits, or Scholars' (Sprat, 1966/1667: 113). Long before the term "populism" was coined in the USA in the late nineteenth century (Chambers, 2006), populist attitudes may have been informing the idea of science as a cause. But how does this combine with the equally old idea of a deficient public, inferior to science, which seems rather to indicate an elitist understanding of science?

The ambiguities make sense if discourses on science communication - and, broader, on the science-society relationships - have actually been tied continuously to an elitism-populism axis, appearing to be part of the natural order and only allowing movement between its poles. This interpretation might even help us understand why exchanges on science communication have been continuously pervaded by the idea of just two groups, scientists and the lay masses of commoners, whether sharply contrasted in top-down approaches or urged to enter into dialogues. It also directs attention to the question of how assumptions of very limited intellectual capacities in the general public may hamper public exchanges about complex, science-related public affairs. The recent decades of critical discussions on science communication have, however, primarily paid attention to other issues.

\section{CHANGE AND CONTINUITY}

During the most recent half-century, the use of scientific methods have actually been extended to almost every branch of thought and to almost all walks of individual and societal life. Current knowledge societies are permeated by scientific knowledge claims and modes of thinking. Most public affairs now come with scientific elements and, then, tend to be seen as (scientific) knowledge problems rather than as science-related public affairs, to be re-solved (Rittel and Webber, 1973) politically by way of public exchanges, deliberation and negotiations. The move to that direction began more than 350 years ago and has been characterised throughout by scientific expansion accompanied by increasing specialisation. It has gathered pace in particular since the 1960s, marked, not least, by developments within the biological and the social sciences, by increasing amounts of science on science - and by concerns about a knowledge deficit in the general public.

\section{Science conflicts, but communication consensus}

During the 1960s, scientific methods came into use as means to document adverse effects of science-based technologies. Along with the environmental movement, the field of environmental 
science evolved as a response to the widespread application of science-based technologies in the production sphere. Science and technology critique went scientific and became, at the same time, exposed to deficit accusations; that is, to the claim that the critique was based on inadequate knowledge and appreciation of - science. Thus, probably, some of those seeds were sown which would later develop into the coining of the deficit model as a critical term within another new field of study: science studies.

That kind of critique, however, was not on the agenda when, in 1969, sociologist Hilary Rose and biologist Steven Rose published a joint enquiry into the science-society relationships. Scientific rationality was expanding to ever more areas, they found, but 'the gulf between the research activities of the scientists and popular understanding and aspirations' was 'still deep'. Science had become 'esoteric, accessible only to the high priests, and beyond the comprehension of the laity'; and 'the "everyman his own scientist" ideal' was merely a 'rosy' ideal (Rose and Rose, 1971: 253-254).

The Roses were concerned that 'an erroneous "image" of scientists or engineers among the young' seemed to deter young people from studying science (Rose and Rose, 1971: 260). It was not, they found, 'the procedures of natural science which are at fault, but its goals' (Rose and Rose, 1971: 262). Against this background, they declared their commitment to 'goals of creating an open, accessible and man-centred science' and to a science which was 'effectively planned according to technocratic criteria' (Rose and Rose, 1971: 268).

Only a few years earlier, calls for increased science communication had come from a completely different corner of biology. At a November 1962 London symposium on developments in biology and medicine, organised by the CIBA Foundation, Nobel Prize winner Francis Crick, identified the 'great lack of biological knowledge among ordinary people' (Wolstenholme, 1963: 274) as an impediment to the progress and application of biological research. The progress Crick had in mind was the introduction of eugenic measures. Biological education was important, he found, because it enabled 'the solutions to be attained with less stress to the social system' (Wolstenholme, 1963: 284). Not all of the 26 other prominent symposium participants were equally keen on eugenics, but Crick's identification of a knowledge deficit in the public gained widespread support. To 'educate people more in biological facts' was described as 'a necessary preliminary to any action' (Wolstenholme, 1963: 367). The 'average man', it was argued, must be taught to 'understand and appreciate the world that scientists have discovered' (Wolstenholme, 1963: 255). That "average man", in turn, was compared unfavourably to the 'better people' who were taken to be marked by 'creativity, intelligence, and the leaning towards science' (Wolstenholme, 1963: 290).

There was continuity: How ever much they differed in other respects, representatives of science, exhibiting a shared enthusiasm on behalf of science, identified a knowledge deficit in the general public and assumed that with respect to knowledge-related issues, society is divided into two groups: scientists and the laity. These basic features were maintained in the Royal Society's 1985 report on the public understanding of science, preparing the ground for a surge of science communication studies and for a division into opposing camps (Einsiedel, 2007), disagreeing in particular on the issue of the deficit model.

\section{Change: Critique from a social perspective}

During the most recent decades, work in the wide field of science and technology studies has resulted in a vast literature on the science-society relationships as seen from a social perspective. In the process, the deficit model term has been coined as a critical term, and the model has been exposed as the expression of an elitist, one-way and top-down attitude to science communication.

Some critics have concluded that scientists are power-holders on a par with other powerholders (Goede, 2002). More often, however, critics viewing the conventional deficit model from a 
social perspective have contributed to the development - forming part of wider societal trends - of a socio-technical complex of interactive didactic methods.

Viewing human beings from the outside, as one of those animal species that live in groups, the social perspective comes with an affinity for technical approaches to human affairs and relations. It brings into focus status and power relations and the degree of distance or intimacy among or within groups as objects of observation and as possible targets of intervention aimed at affecting social relations or mechanisms of or among groups. Accordingly, the critique of the deficit model as one-sided has given rise to the development of methods aimed at furthering two-way approaches and connected to a cluster of such notions as dialogue, empowerment, inclusion and participation. Moving along the elitism-populism axis, the emphasis on public understanding of science has been replaced by an emphasis on public engagement with science, and popularisation efforts have been widened to include aims of uniting the scientific elite and the lay crowds in a commitment to science as a shared cause. This participatory turn, including its dialogue enthusiasm, has even been adopted by public authorities as an efficient and confidence-(re)building approach to science didactics (European Commission, 2007; House of Lords, 2000).

At the same time, the binary logic of stark dichotomies, forming part of the philosophical foundation of modern science, has been targeted. In particular, critical attention has been paid to assumptions of a truth-versus-the-social-sphere dichotomy, and the breaking down of (perceived) boundaries between such (perceived) spheres of, respectively, purity and corruption, has attained the status of a cause in its own right.

Dichotomies represent mutually excluding opposites, like the two sides of the same coin. Ignoring this peculiar quality of dichotomic distinctions, attempts to escape dichotomic deadlocks have taken the overall form of an assault on the practice of making distinctions at all. The idea has been refused that science belongs in a separate sphere of truth as opposed to a social sphere of human relations and interests. In the same breath, any idea of knowledge formation as distinct from other societal activities has been discarded. Such distinctions have come to appear as the root cause of the deficit model. Consequently, the very concept of science has come under attack ${ }^{1}$.

There is, an influential line of argument goes, no such thing as science, only knowledges. Or there is 'everyday scientific knowledge ("ethno-science")' or " "ethno-natural knowledge" as opposed to '(professional) science' or to 'élite science (including what is now called "social science")'. Or there is after all such a thing as science, but only in the sense of 'a multifaceted and highly flexible symbolic resource of multiple meanings' (Cooter and Pumfrey, 1994).

According to an even more influential line of argument there is no such thing as the public either, only publics. When seen from the social perspective, this is a significant improvement. The identification or construction of social groups is based on observations of shared features. Social groups are defined by homogeneity. Clearly, the general public is too diverse to constitute a social group. So, publics has become the standard term. This social, as distinct from political, perception of the public(s) counters demeaning understandings of the public as one single mass of equally ignorant nonentities, understandings that have often appeared inseparable from class prejudice. It does, however, nothing to include scientists in the public(s). Actually, it may serve to bolster an understanding of scientists as a particular social (elite) group.

\section{Continuity: the elusive concept of politics}

\footnotetext{
${ }^{1}$ Also, the status of science studies has become unclear. Are they (social) science on (techno) science or merely, for instance, social research? What is and what should be the role of social science (or social research?) in science communication? Should social science be disseminated like natural science? Or should social science rather - or at the same time - describe communication mechanisms and prescribe communication methods?
} 
A political category of science communication as public discussions on science-related public affairs makes little sense if there is no such things as science, if the public is merely a number of disconnected social groups and if, indeed, there is no such thing as politics as anything other than either the irrational opposite or the rational application of science.

Substantial ideas of politics have remained largely absent even during the most recent decades of critical debate. One comes across references to 'public policy-making and public debate' (Trench, 2008) and 'processes of deliberative democracy' (Durant, 1999); but the possible substantial differences between science and politics and their respective concerns and fields of practice remain opaque. Indicating that science somehow trespasses onto foreign domains, the notion of "scientism" has been introduced (Trench, 2008; Welsh and Wynne, 2013; Wynne 2006, 2014), but besides the occasional reference to the conventional idea(l) of science as pure descriptivity and politics as pure normativity it has not been accompanied by suggestions concerning the domain proper of science.

Along related lines, distinctions between social (in)equality and political (in)equality are hardly ever drawn. Rather, social technologies aimed at including, empowering and engaging seem linked to goals of fighting inequality and furthering equality in general. That, in turn, means that the peculiar quality of political (in)equality is ignored. A brief excursion into a coffee house reflection might serve to illustrate the point.

Characterising the coffee houses as information centres, Richard Sennet (1986/1977) noted that people went there 'to gain knowledge and information through talk'. Therefore, according to Sennet, 'distinctions of rank were temporarily suspended', and it was 'bad form even to touch on the social origins of other persons when talking to them in the coffeehouse, because the free flow of talk might then be impeded' (Sennett, 1986/1977: 81).

This depiction of the coffee house practices of the eighteenth century may well be romanticised, but that does not make the fundamental point less salient: Having a discussion on equal terms may be hampered by emphasising social (in)equalities - but that is precisely what the current socio-technical complex of interactive didactive methods does. It focuses on and directs attention to (social) inequalities, defining target groups as excluded and powerless. The aim is to do away with inequalities, but the emphasis may be partly counterproductive. Potentially, it may undermine political equality as a kind of equality that human beings ascribe to each other, formally in the shape of civil rights, informally by accepting each other as participants on equal terms in discussions of public affairs. Methods aimed at empowering, including and making people participate are based on the presupposition of deficits in the target groups. This is unlikely to further exchanges on equal footing and may even divert attention from the substance of the issues for discussion.

All in all, understandings of science communication that presuppose deficit models of the public(s) seem to have survived the critical debates of the most recent half-century. This is supported by the facts that understandings of science communication as a popularisation and dissemination task have been left almost unscathed (McNeil, 2013) and that the notion of the laity has remained widely used.

Also, the widespread and awkward juxtaposition of the "public understanding of science" with "scientists' understanding of the public" indicates that there is more thinking to do. A seemingly impersonal force or institution, science, and a lot of persons, the public(s), are not comparable entities and could not possibly be brought to understanding each other. Why not "scientists' understanding of other kinds of reasoning?" Is science ascribed a monopoly on reason? The relatively recent notion of 'scientific citizenship' (Felt, 2003) begs related questions. Aimed at enabling citizens in general to adopt scientific frameworks of thought, it appears as a replica of the 
time-honoured "Everyman as scientist" ideal, coined by critics in the late 1960s (Rose and Rose, 1971: 253).

\section{ACKNOWLEDGING THE CITIZENSHIP OF SCIENTISTS}

Based on deeply rooted beliefs in the primacy of science in all aspects of life, repeated attempts have been made to include all citizens in the scientific endeavour. Some such attempts have been motivated primarily by straightforward science enthusiasm and a positive belief in the cause of science as universal light. Other attempts have been based, no less enthusiastically, on inverted versions of that belief - acknowledging, so to speak, no light anywhere - or have been motivated primarily by anti-elitist sentiments. In any case, substantial ideas of politics as anything other than either the irrational opposite or the rational application of science have remained absent, and science communication discourses have remained tied to an elitism-populism axis founded on the assumption of absent intellectual capacities in the general public.

It would not, however, be logically impossible to think otherwise, based on other assumptions about politics. Such assumptions are present in, for instance, classical political thought along Aristotelian lines.

Modern science evolved in opposition to 'the relics' (Sprat, 1966/1667: 121) or 'the tyranny' of antiquity (Bury, 1955/1932: 16) and, in particular, to Aristotelian lines of thought (Toulmin, 1990). The classical understanding of human life - political life included - as fundamentally uncertain and unpredictable practice (praxis) was replaced by general aims of gaining control. The classical distinctions between universal truths, technical problem-solving and practical human affairs were substituted by the idea of science as universal light. The emphasis on the ability to make personal judgements from one case to another, pivotal to the Aristotelian idea of practical reason (phronesis), was taken over by 'distrust of personal judgment' (Porter, 1995: 200).

The concept of praxis captures an idea of human life, and the world of human affairs, as marked by limitations and restrictions (for elaboration, see for instance Arendt, 1969/1958; Crick, 2005/1962; MacIntyre 1984). There are no absolutes or certainties. Life is action (praxis) as distinct from production (Aristotle, 1992: 1244a1). Limitations and restrictions relate to time, space and biological needs and to the fact that human beings are many, and all use different perspectives in the world. The latter fact, however, is not seen merely as a restriction. Combined with the interconnected capacities for thought and speech that characterise human beings as political animals, the basic fact of human diversity also enables humans to deal with practical questions in a specifically human way: exchanges among multiple points of view, delimiting and making room for each other. There are no universally valid solutions to practical problems, no possibility of identifying cause-effect connections and gaining control. There is diversity and disagreement, unpredictability and uncertainty ${ }^{2}$. Therefore, discussion between different points of view is the political mode.

Politics is considered the most difficult and worthiest form of practice, relying on the exercise of practical reason as distinct, at the same time, from the contemplation of universal truth, and from instrumental, technical rationality, connected to the production and control of things and including the possible use of force (Arendt, 1958-1959). Politics in this sense is neither an instance of cynical power play; nor is it the domain of a modern, rational apparatus of state; nor does it epitomise ideological warfare between partisan activists. Instead, it signifies attempts by the public of co-responsible citizens to deal discursively with practical-political issues on the basis of practical reasoning.

\footnotetext{
${ }^{2}$ Horst Rittel and Melvin Webber (1973) have provided a useful characterisation of practical questions, although oddly dubbed 'wicked problems'.
} 
Practical reasoning signifies the exercise, from one situation to another, of personal judgement concerning the lay of the land and the possibilities for reasonable and justifiable action. Drawing on experience, human reality is viewed from within and ethical concerns are seen as elements of any practical assessment. Discussion among practical reasoners, in this view, is not as a social means to achieve intimacy, but a practical form of enquiry into human affairs (Aristotle, 2002), connecting thought and speech and different points of view (Crick, 2005/1962), and including different perspectives of human reality.

As a practical-ethical concept, the public - or citizenry - is composed by the diverse plurality of individual citizens, scientists not excluded, who are bound together by shared responsibility for public affairs. These affairs, in turn, relate to practical questions that are taken to be capable only of being resolved temporarily and case by case by means of discussion, deliberation and negotiation.

This pluralistic understanding of politics marks it out as substantially different from modern science, circling the concept of universal truth and operating on the lines of technical rationality. Thereby, it makes room for both. It is not hostile to modern science, but it does claim a domain of its own and takes the domain of science to be different. This is based on the crucial distinction between technical-scientific and practical-political questions and constitutes a challenge to ideas of science as universal light and an all-purpose problem-solver. Both rooms come - as rooms do with boundaries, although those boundaries cannot be defined once and for all.

Theoretically, this framework of thought might facilitate the introduction of a political category of science communication, accommodating discussion among politically equal citizens on science-related practical-political issues. Different from but not hostile to didactic science communication it would be aimed at integrating natural and social scientific knowledge claims and concerns into the wider context of societal practice (Gadamer, 2001: 568).

In knowledge societies pervaded by scientific approaches, many, perhaps most scientific projects are somehow connected to practical-political questions in the classical sense. Conversely, most practical-political problems include scientific components. At the same time, the practices of doing science and developing technologies appear as instances of praxis; they are human endeavours subject to the practical conditions of uncertainty, unpredictability and human diversity. The practical-political and the technical-scientific are intertwined. Thus, in practice the categories of didactic and political science communication would often overlap. Nevertheless, applying the distinction - a key practical task in its own right - might still support assessments of how to communicate about science from one case to another.

Only, the distinction between the practical and the technical - always rather abstract, but hardly more so than ideas of pure descriptivity and pure normativity - has no place in the dominant schemes of thought on science. The classical concept of practice has been devoured by the notion of technical instrumentality. All problems tend to be seen as technical-scientific problems. Science communication, then, becomes a matter of transferring knowledge from knowers to non-knowers. And a practical-political category of science communication, in the shape of exchanges between different perspectives on reality, does not make sense.

Vis-à-vis science there is, it seems, no need for a critical public - but, it has been argued, a critical public is an asset for the future of science (Bauer, 2009; Durant, 1999). Drawing on classical political thought, a stronger argument may be made: A critical public constitutes, at the same time and for the same reasons, a necessary condition for the maintenance of democratic knowledge societies as political entities and of science as a body of knowledge and rational methodology. I wish to make this stronger argument, understanding a critical public to include a sufficiently large number of citizens who actually concern themselves with the issues and substance of public representations of science to maintain public discussion between different points of view. 
The argument follows, firstly, from the identification of discussion among multiple points of view, delimiting and making room for each other, as the practical-political mode. Secondly, it follows from the understanding of scientific research as a human activity, subject to the practical conditions of uncertainty, unpredictability and diversity, and dependent on its own capacity to delimit itself and have exchanges with other human activities. Deprived of critique from other points of view, science as a body of knowledge and rational methodology might lose that capacity. Expansion, then, might continue to the point of explosion, reducing all exchanges on science-related public affairs to perpetual chains of science-on-science-on-science kinds of argument and leaving no space for discussion among different points of view.

From a science-as-a-cause position, such complete victory might seem desirable. To science as a body of knowledge and rational methodology, however, the victory would be Pyrrhic. In order to maintain its wider societal context, science, in that sense, needs a political category of science communication, featuring citizens on an equal footing - some of them scientists - who represent different points of view and ways of reasoning and share responsibility for public affairs. This might be facilitated by the acknowledgement of the citizenship of scientists, appreciating, at the same time, their technical-scientific knowledge and, with respect to practical-political aspects of issues, their status as citizens among other citizens. Only, this is not an easy way out of current problems. It would require scientists and the societies they form part of to critically revise the ancient idea of science as universal light and to ponder, over and over again, how to distinguish between technical-scientific and practical-political issues.

\section{References}

Arendt H (1958-1959). Kultur und Politik. Merkur, Deutsche Zeitschrift für Europäisches Denkens 12: $1122-1145$.

Arendt H (1969/1958) The Human Condition. Chicago and London: The University of Chicago Press.

Aristotle (1992) The Politics. Translated by T.A. Sinclair (1962). Revised and re-presented by Trevor J. Saunders (1981). London: Penguin Classics.

Aristotle (2002) Retorik. Translated by Thure Hastrup. Copenhagen: Museum Tusculanums Forlag.

Bauer MW (2009) The evolution of public understanding of science - discourse and comparative evidence. Science, Technology and Society 14(2): 221-240.

Bauer MW, Allum N and Miller S (2007) What can we learn from 25 years of PUS survey research? Liberating and expanding the agenda. Public Understanding of Science 16: 79-95.

Bodmer W (2010) Public understanding of science: The BA, the Royal Society and COPUS. Notes and Records (of the Royal Society) 64: 151-161.

Bury JB (1955/1932) The Idea of Progress: An Inquiry into its Origin and Growth. New York: Dover Publications, Inc.

Butterfield H (1957/1949) The Origins of Modern Science: 1300-1800. London: G. Bell and Sons Ltd. Retrieved from

https://ia802300.us.archive.org/27/items/originsofmoderns007291mbp/originsofmoderns007291mb p.pdf

Chambers dictionary of etymology (2006) Edinburgh and New York: Chambers.

Coltman I (1962) Private Men and Public Causes: Philosophy and Politics in the English Civil War. London: Faber and Faber.

Cooter R and Pumfrey S (1994) Separate spheres and public places: Reflections on the history of science popularization and science in popular culture. History of Science 32: 237-267.

Crick B (2005/1962) In defence of politics. London and New York: Continuum. 
Durant J (1999) Participatory technology assessment and the democratic model of the public understanding of science. Science and Public Policy 26: 313-319.

Einsiedel E (2007) Editorial: Of publics and science. Public Understanding of Science 16: 5-6. European Commission (2007) Public Engagement in Science. EUR 23334. Luxembourg: Office for Official Publications of the European Communities. DOI: $10.2777 / 20800$

Felt U (ed.) (2003) O.P.U.S. Optimising Public Understanding of Science and Technology: Final Report. Available at http://www.univie.ac.at/virusss/opus/mpapers.html

Friedman SM, Dunwoody S and Rogers CL (eds) (1986) Scientists and Journalists: Reporting Science as News. New York and London: The Free Press.

Gadamer H-G (2001/1975) Afterword. In: Gadamer HG Truth and Method. Second, revised edition. London: Sheed \& Ward, pp. 551-580.

Goede W (2002) Civil Journalism \& Scientific Citizenship: Scientific Communication "of the people, by the people and for the people. Keynote address to the Third World Conference of Science Journalists. Available at: http://comm-org. wisc.edu/papers2003/degoede.htm

Hill C (2010/1961) The Century of Revolution: 1603-1714. London and New York: Routledge. Hobsbawm E (1995) Age of Extremes: The Short Twentieth Century 1914-1991. London: Abacus. House of Lords Select Committee on Science and Technology (2000) Third Report: Science and Society. Available at:

http://www.publications.parliament.uk/pa/ld199900/ldselect/ldsctech/38/3801.htm

MacIntyre A (1984) After Virtue: A Study in Moral Theory. Notre Dame, IN: University of Notre Dame Press.

McNeil M (2013) Between a rock and a hard place: The deficit model, the diffusion model and publics in STS. Science as Culture 22(4): 589-608.

Midgley M (1992) Science as Salvation: A Popular Myth and its Meaning. London and New York: Routledge.

Morgan ES (1989) Inventing the People: The Rise of Popular Sovereignty in England and America. New York and London: W.W. Norton \& Company.

Ortega y Gasset J (1993/1930) The Revolt of the Masses. New York: Norton.

Porter R (2001) Enlightenment: Britain and the Creation of the Modern World. London: Penguin Books.

Porter TM (1995) Trust in Numbers: The Pursuit of Objectivity in Science and Public Life. Princeton, NJ: Princeton University Press.

Rittel H and Webber M (1973) Dilemmas in a general theory of planning. Policy Sciences 4: 155-169.

Rose H and Rose S (1971) Science and Society. Harmondsworth: Penguin Books.

Royal Society, the (1985) The Public Understanding of Science. Report of a Royal Society ad hoc Group endorsed by the Council of the Royal Society. London: The Royal Society.

Sennet R (1986) The Fall of Public Man. London: Faber and Faber

Sprat T (1966/1667) History of the Royal Society. Edited with critical apparatus by Jackson I. Cope and Harold Whitmore Jones. London: Routledge \& Kegan Paul Ltd.

Sturgis P and Allum N (2004) Science in society: Re-evaluating the deficit model of public attitudes. Public Understanding of Science 13: 55-74.

Toulmin S (1990) Cosmopolis: The Hidden Agenda of Modernity. New York: The Free Press.

Trench B (2008) Towards an analytical framework of science communication models. In: Cheng D, Claessens M, Gascoigne T, Metcalfe J, Schele B and Shi S (eds) Communicating Science in Social Contexts: New Models, New Practices. Dordrecht: Springer, pp. 119-138.

Veblen T (1899) The Theory of the Leisure Class. Available at: http://xroads.virginia.edu/ HYPER/VEBLEN/veb_toc.html 
Wells HG, Huxley J and Wells GP (1929-1930) The science of life: A summary of contemporary knowledge about life and its possibilities. Part 1-31. London: The Amalgamated Press Ltd.

Welsh I and Wynne B (2013) Science, scientism and imaginaries of publics in the UK: Passive objects, incipient threats. Science as Culture 22(4): 540-566.

Wolstenholme G (ed.) (1963) Man and his Future. A Ciba Foundation Volume. London: J. \& A. Churchill Ltd.

Wood GS (1993) The Radicalism of the American Revolution. New York: Vintage Books.

Wynne B (2006) Public engagement as a means of restoring public trust in science: Hitting the notes, but missing the music? Community Genetics 9: 211-220.

Wynne B (2014) Further disorientation in the hall of mirrors. Public Understanding of Science 23: 60-70. 